\title{
Representasi Wanita Dalam Media Massa Masa Kini
}

\author{
Errika Dwi Setya Watie \\ (errikadwisw@yahoo.com) \\ (Pengajar Jurusan Ilmu Komunikasi Universitas Semarang)
}

\begin{abstract}
Media audience, in general, using representation of women in the media to "see" women. How does the media show the figure of a woman often becomes references and examples used to assess women in general. Not only how man seeing woman, but women see themselves and other women see each other. This condition seemed to reinforce the encouragement of women to remain in the view of women in the past is loaded with socio-political. In many media, women are still portrayed as "mere body" related to sexuality. Besides the still dominant view that shows women as "a figure in the kitchen", the less equilibrate view that showing women in the intellectual and career figures, reinforce the representation of "traditional" women. And finally appeared in public perception will remain the same. Representation of woman according to the spirit of emancipation of women only appears in the commemoration of Kartini day, mothers day, and other momentum associated with women.
\end{abstract}

Kata Kunci : Woman, Representation

\section{Pendahuluan}

Banyak yang mengatakan, saat ini emansipasi wanita telah berjalan dengan baik. Posisi wanita di berbagai bidang telah telah banyak diakui. Namun demikian, benarkah realita demikian yang terjadi?? Perlu kiranya hal tersebut dikaji lagi, bukan untuk mempertanyakan dan meragukan, namun untuk lebih mengetahui apa yang terjadi sebenarnya pada wanita masa kini. Perhatian jurnal ini akan mengerucut pada representasi wanita pada media masa kini. Diharapkan berangkat dari jurnal ini, bisa menjadi awal mula penelitian lebih lanjut terkait bagaimana sebenarnya posisi wanita di masyarakat sebenarnya.

Representasi wanita di media, banyak dijadikan acuan masyarakat umum, audience media, untuk "melihat" wanita. Bagaimana media menampilkan sosok wanita sering kali menjadi acuan dan contoh yang digunakan untuk menilai wanita pada umumnya. Bukan hanya mereka yang berlainan gender terhadap wanita, tetapi juga wanita melihat diri mereka sendiri dan melihat sesama wanita lainnya.

Dunia saat ini telah dipenuhi oleh media. Saluran televisi dan stasiun radio hampir tak terhitung jumlahnya hadir bagi kita. Berbagai media cetak, seperti surat kabar, majalah, buku, komik, dan juga berbagai video, film, animasi saling bersaing untuk menarik perhatian kita dan menyita waktu kita. Kehadiran iklan pun hampir tidak mungkin lagi kita hindari. Ditambah kini dengan hadirnya internet, surfing di internet sudah menjadi aktivitas sehari hari di masyarakat kita. Berbagai pilihan informasi ditawarkan bagi kita, dan tanpa kita sadari, ketika kita menikmati dan menerima informasi yang disampaikan media tersebut, kita sedang menciptakan makna bagi kita sendiri. Maka, wajar jika media informasi massa memberikan pengaruh 
dalam membentuk kesadaran masyarakat, salah satunya terhadap perempuan, baik positif ataupun negatif.

Berdasarkan uraian diatas, maka tulisan ini akan mencoba mengurai bagaimana representasi perempuan di media masa kini, tentunya media yang beredar di Indonesia. Tentu saja representasi wanita dalam media di Indonesia tersebut akan mampu mewakili representasi wanita Indonesia di media masa kini. Sehingga nantinya hal ini bisa menjadi awal untuk melihat representasi wanita di media secara lebih luas nantinya.

\section{Pembahasan}

Analisis isi dan media

Isi pesan yang disampaikan media penting untuk dipelajari dan diteliti, karena isi pesan yang disampaikan media ini dipercaya akan memiliki efek/mempengaruhi audiencenya. Analisa isi atau content analisys penting karena merupakan alat bagi para peneliti untuk mengeksplorasi lebih jauh tentang bagaimana proses kognitif individual berjalan dan pengaruh yang berjalan terkait dengan karakteristik pesan yang disampaikan. Namun demikian, penelitian analisa isi perlu dilakukan secara hati - hati dan sistematis, karena hasil yang didapat bisa berperan sebagai penyebab/ antecedent dari berbagai proses individual, efek dan penggunaan orang akan sesuatu. Beberapa hasil dari content analysis, merupakan gambaran kenyataan, yang bisa digunakan untuk melukiskan suatu kelompok, fenomena, sifat atau karakteristik yang berlawanan dengan standar yang digunakan dalam kehidupan nyata.

Pengamatan pada materi dalam media merupakan satu cara mendasar dalam studi media, disini teks diartikan sebagai semua materi yang dimuat di media. Teks dapat 'dibaca'. Teks akan disusun dengan cara tertentu. Inti dari penganalisaan isi media adalah kita dapat memahami prinsip penyusunan teks dalam media. Jika dapat dipahami prinsip penyusunannya, maka dapat dianalisis cara berbagai hal dikatakan, sehingga akan memperbesar kemungkinan untuk memahami apa yang dimaksud oleh materi.

Umumnya dikatakan, teks adalah hasil kecerdasan manusia/ artifact, yang bisa di teliti dan diinterpretasikan. Teks itu sendiri berbicara pada kita, dan memiliki pemaknaan tersendiri terpisah dari maksud penulisnya. Menurut HansGeorg Gadamer, proses interpretative ini merupakan suatu paradox, dimana kita membiarkan teks berbicara pada kita, namun kita tidak bisa memahaminya secara terpisah dari dugaan dan pekiraan kita.

Media mendistribusikan pesan pesan dan merefleksikan budaya dari masyarakat. Media menyediakan informasi secara simultan kepada audience yang heterogen dan banyak, dimana hal ini membuat media sebagai bagian dari tekanan institusional dalam masyarakat. Pesan media muncul dari perspektif semiotik karena biasanya terdiri dari percampuran antara simbol simbol yang diatur dengan bebas dan secara kronologis untuk menciptakan suatu kesan, penyaluran gagasan atau mendatangkan pemaknaan bagi audience. Semiotik membantu kita melihat bagaimana tanda - tanda digunakan untuk menginterpretasikan kejadian dan bisa menjadi alat yang sangat baik untuk menganalisa isi pesan media.

Jean Baudrillard, mempercayai, bahwa tanda telah menjadi sangat terpisah dari obyek yang diwakilinya, dan bahwa media mendorong proses ini 
ke satu titik dimana ketiadaan adalah nyata. Saat ini kita ada di era simulasi, dimana tanda bukan lagi merepresentasikan namun menciptakan realita kita. Simulasi menentukan siapa kita dan apa yang kita lakukan, tanda membangun pengalaman kita. Media mendominasi hidup kita dengan informasi yang membentuk apa yang kita rasakan sebagai pengalaman asli, namun dihilangkan dari tujuan alami sesuatu. Budaya komoditas merupakan satu aspek dari simulasi dimana kita hidup. Lingkungan yang tersimulasi memberitahu kita apa yang kita inginkan. Kebanyakan, nilai dan perilaku seseorang kemudian sangat dibatasi oleh realita yang disimulasi dalam media.

Media mampu membentuk kekuatan besar dalam masyarakat. Media, terlepas dari apapun isi medianya, mengharuskan kita berpikir secara kritis dan kreatif tentang media yang kita konsumsi, bagaimana media mempengaruhi kita sebagai individu dan bagaimana media membentuk budaya dan masyarakat kita. Menurut Donald Ellis, media utama pada suatu waktu akan membentuk perilaku dan pemikiran. Saat ada perubahan pada media, maka berubah pula cara berpikir kita, pengelolaan informasi, dan menghubungkan satu sama lain. Media tertulis membawa perubahan besar dalam masyarakat, ketika kita menulis sesuatu, kita bisa memisahkannya dari waktu, kita bisa memanipulasinya, merubahnya, mengeditnya serta membuat ulang. Hal ini membawa pemisahan antara pengetahuan dari orang yang mengetahui. Pengetahuan menjadi obyektif dan bisa mengasumsikan status kebenaran, dan bisa dipisahkan antara mereka yang memiliki kebenaran dan yang tidak. Informasi bisa disimpan, diamankan, yang membuat literature sebagai alat konservatif.

Thomas Lindlof menuliskan ada tiga dimensi dari suatu komunitas interpretative, dimana dia menyebut elemen ini sebagai genre - genre. Genre pertama, adalah content/ isi, yang terdiri dari pengkonsumsian berbagai tipe program dan media lainnya oleh komunitas. Genre kedua adalah interpretation/interpretasi, yang berkisar seputar pemaknaan bersama, dimana anggota komunitas menginterpretasikan isi program dan media lainnya dengan cara yang hampir sama. Dampak pada perilaku mereka, terutama apa yang mereka katakan tentang media dan bahasa yang digunakan untuk menggambarkannya, memiliki kemiripan. Genre ketiga adalah social action/tindakan sosial, yang merupakan serangkaian perilaku bersama terhadap media, termasuk bukan hanya bagaimana isi media dikonsumsi (kapan dan dimana isi media dilihat atau dibaca), namun juga cara - cara isi media ini mempengaruhi kelakuan anggota komunitas.

Komunikasi massa melibatkan adanya penyebaran informasi dan pengaruh dalam masyarakat melalui media dan saluran interpersonal. Media mempengaruhi cara kita berpikir dan melihat dunia, bahkan media berpartisipasi dalam banyak penciptaan budaya itu sendiri, dan banyak yang percaya bahwa media merupakan alat penyebaran kekuatan dan dominasi di masyarakat serta merupakan alat untuk penyebaran ideology dan hegemony.

Stuart Hall dan koleganya mengungkapkan, adanya pemaknaan kultural atas produk media, dimana cara - cara isi media diinterpretasikan secara berbeda oleh kelompok dominan dan opposisional. Budaya dibentuk melalui pertarungan ideologi dan interpretasi 
atas pesan media akan selalu muncul dalam perjuangan kontrol ideology. Komunikasi, terutama yang melalui media, memiliki peran khusus dalam mempengaruhi budaya populer. Terry Lovell, Fern L. Johnson dan Karen Young menyatakan bahwa hubungan kekuatan dibentuk dalam berbagai interaksi sosial dan bahwa bahasa dan bentuk simbolik terus menciptakan kategori berpikir dan hubungan sosial. Dalam hal ini media juga seringkali berperan dalam pembentukan stereotip gender, melalui isi pesan yang disampaikannya, serta menciptakan stereotip cultural dengan menggunakan pesan yang disampaikannya untuk tujuan pemasaran.

Berbagai gerakan dan usaha mendorong adanya emansipasi perempuan hingga saat ini masih berjuang mancapai keberhasilannya. Gerakan emansipasi ini berusaha mewujudkan disegala lini kehidupan, akan adanya persamaan hak dan kedudukan atau posisi sosial politik yang sama antara pria dan perempuan. Media informasi disini sebenarnya juga memainkan peran dalam membentuk gambaran tentang laki - laki dan perempuan, di dalam pikiran individu individu masyarakat seluruhnya tanpa ada pembedaan, antara yang besar atau yang kecil, yang kaya atau yang miskin, khususnya di area nilai - nilai, tradisi tradisi sosial, dan etika yang melampaui batasan - batasan kemiskinan dan kekayaan.

Wajar jika media informasi memberikan pengaruh dalam membentuk kesadaran masyarakat terhadap perempuan, positif ataupun negatif, dengan bantuan pesan - pesan informatifnya yang dimuat dan disebarkan melalui berbagai bentuk media informasi yang ada termasuk majalah. Pengaruh negatif media informasi tentang perempuan berjalan melalui pembentukan, pengukuhan dan publikasi gambaran - gambaran negatif yang telah mengakar tentang perempuan yang patuh, baik dalam pikiran kaum pria, bahkan perempuan sendiri hingga anak - anak. Banyak pihak ini sama sekali tidak meragukan keabsahan gambaran tersebut, dimana produksi ideology kembali pada "keunggulan laki - laki" yang membuat perempuan tetap berada dalam keadaan yang "menyedihkan". Disini media seringkali secara tidak sadar juga menjadi pelaksana tradisi - tradisi yang tidak mampu mengeluarkan perempuan dari area diskriminasi.

Perempuan dalam media seringkali digambarkan sebagai obyek tatapan pria. Para model yang nyaris telanjang pada sampul majalah pria menjadi hal yang biasa. Para presenter program televisi populer, seringkali dipilih berdasarkan wajah mereka dan bukannya berdasarkan bakat yang lebih substansial. Salah satu stereotip perempuan yang paling umum adalah istilah "bimbo"- perempuan dengan rambut pirang, tata rias tebal, dada besar, rok mini, dan sepatu hak tinggi yang distereotipkan sebagai perempuan yang gampangan, bodoh, tidak berpendidikan dan tidak berdaya. Dalam kultur postmodern, istilah ini mengandung konotasi buruk. Ironisnya, meskipun tidak mengejutkan, perempuan sendiri sering kali tidak berhati - hati dalam pembuatan dan kontruksi stereotip gender yang menyimpang tersebut.

Media pasti memiliki sasaran audience, termasuk juga ada media dengan sasaran audience perempuan. Jelas disini, media dengan sasaran audience perempuan, bisa secara kontinyu dan intens memberikan informasi kepada perempuan pada 
khususnya, dan masyarakat pada umumnya, tentang sosok perempuan itu sendiri. Sehingga melalui segala muatan/ isi yang ada di dalamnya, media perempuan jelas memiliki kewajiban tak tertulis untuk turut serta memajukan perempuan, memberi pemahaman yang lebih baik dan berkembang tentang diri perempuan.

Cobalah simak tampilan iklan di media sekitar kita belakangan ini, baik elektronik maupun cetak, selain dipenuhi gaya pria perlente, juga bertaburan dengan aksi perempuan ayu dan seksi, namun kesan yang muncul tetap saja menunjukkan lelakilah yang lebih dominan. Menurut Deddy Mulyana dalam buku Sihir Iklan karangan Wahyu Wibowo, kebanyakan iklan di media massa merupakan reproduksi stereotip peran tradisional kaum perempuan. Pria dan perempuan digambarkan sebagai dua makhluk yang memiliki dunia yang berbeda. perempuan digambarkan hanya peduli dengan rumah tangga dan penampilan fisik mereka. Sedang kepedulian lelaki dikesankan hanya di sekitar bisnis, mobil dan olah raga. Iklan produk kecantikan (bedak, deodorant, shampoo, make up, sabun dan lainnya) melukiskan bahwa setelah produk ini dipakai sang tokoh perempuan, maka ia akan menjadi 'santapan mata' pria. Kondisi ini makin dipertegas oleh otoritas media massa, yang sangat leluasa 'membuat' perempuan pada akhirnya harus kembali hanya menjadi 'milik' pria. Karenanya, perempuan harus tampil bersih, cantik, manrik, sehat, pintar memasak. Sementara itu, kaum pria sendiri tidak pernah merasa bahwa sebenarnya ia sedang berhadapan dengan 'perempuan palsu', dalam 'peran palsu'nya di 'lingkungan palsu'.
Banyak orang percaya media massa dalam fungsinya memberi informasi, menghibur dan mendidik sangat berperan dalam membangun dunia fantasi. Melalui kata, suara dan gambar, dan apapun yang ditampilkan di dalamnya, media menciptakan kemiripan dengan dunia "nyata". Media memediasi, dengan merepresentasikan dunia kepada audience nya. Dengan mengkonstruksi representasi realitas, media mengkontruksi makna dunia. Stereotip merupakan bentuk paling umum dari representasi oleh media. Stereotip merupakan pelabelan yang mengelompokkan orang, yang umumnya cenderung negatif dan yang dapat dikenakan terhadap seluruh kelompok sosial atau kultural. Beberapa stereotip mendapatkan persetujuan di masyarakat karena digunakan di dalam media secara global. Secara ideologis, stereotip menunjukkan justifikasi posisi istimewa seseorang dan perlakukan yang berbeda terhadap orang lain. Disini stereotip jadi memarginalkan. Teks - teks media mengandung stereotip, dengan menggunakan stereotip, media menciptakan hubungan instant dengan audience. Dampaknya, hal - hal terkait gender, bukan merupakan sesuatu yang sulit dijadikan komoditas di media. Dan bila cover majalah atau tabloid lebih sering dihiasi gambar perempuan, artinya nilai perempuan sebagai manusia telah direduksi menjadi sebatas makhluk biologis semata.

Hal - hal yang direpresentasikan media adalah pandangan - pandangan tertentu dari kelompok - kelompok sosial. Pandangan - pandangan inilah yang dipelajari manusia secara tidak sadar, dan menerimanya sebagai hal yang normal serta mengesampingkan pandangan - pandangan alternatif. Karena itu manusia, dalam hal ini 
audience media hendaknya dengan cermat mengamati representasi representasi yang dihadirkan media kepadanya. Stereotip telah menjadi mapan lewat representasi bertahun tahun dalam media serta lewat berbagai asumsi dalam percakapan sehari - hari. Stereotip tidak selalu buruk atau negatif, sebab baik buruknya, negatif tidaknya suatu stereotip tergantung pada bagaimana hal tersebut digunakan dan pertimbangan terhadap nilai yang diungkapkan. Namun memang, semua tipe representasi/stereotip membawa semacam makna, yang mana makna ini dapat bersifat kritis atau merendahkan terhadap kategori orang yang diciptakan dan direpresentasikan dengan cara tersebut.

Penelitian yang relevan

Salah satu studi paling awal tentang representasi adalah studi yang dilakukan Stan Cohen terhadap Mods and Rockers pada paruh tahun 1960an. Cohen berpendapat bahwa media melabeli kultur anak muda dengan cara negatif dan penuh dengan stereotip, yang lalu memunculkan sebutan "sampah masyarakat".

Studi peran gender pernah dilakukan Lee dan Hoon tahun 1993 terhadap artikel di koran yang menggambarkan perbedaan pria dan perempuan sebagai manager perusahaan. Disana ditemukan bahwa artikel koran tersebut menunjukkan bahwa manajer pria digambarkan dengan gaya managerial yang professional, sedang manajer perempuan selalu digambarkan dengan permasalahannya dan dilemma yang dihadapinya dalam perannya sebagai manajer, istri dan ibu. Disini perempuan jarang ditampilkan secara professional hanya sebagai manajer saja.

Penelitian lain terkait gender, yang membahas tentang perempuan juga dilakukan oleh Dr. Sunarto pada tahun 2007, dalam disertasinya yang telah dibukukan, dengan judul televisi, kekerasan dan perempuan. Dalam penelitian ini ditemukan bahwa fenomena kekerasan terhadap perempuan secara aktual akhir - akhir ini menunjukkan peningkatan berarti, dan fenomena ini ternyata juga ditemui di media massa umum, bahkan ditengarai fenomena serupa juga ditemui dalam media untuk anak anak, baik cetak maupun elektronik. Bahwa telah terjadi naturalisasi kekerasan personal (psikologis, seksual, fungsional) dan kekerasan struktural (dominasi pria atas perempuan, stereotip peran gender, domestikasi dan eksistensinya sebagai profesi, obyektifikasi seksualitas perempuan) terhadap perempuan dalam film animasi anak - anak di televisi.

Kesamaan umum yang ada dari penelitian kali ini dengan penelitian yang diungkap diatas, adalah bahwa semuanya membahas tentang stereorip. Terutama untuk penelitian Cohen dan Dr.Sunarto, sama - sama membahas tentang stereotip representasi perempuan di media massa. Hanya saja bedanya bahwa penelitian kali ini fokus pada bagaimana stereotip representasi perempuan di media massa dengan target audience perempuan sendiri, dalam hal ini media cetak (majalah) perempuan.

Wanita dan media

Saat ini, masalah wanita bukan saja menjadi masalah yang hanya dipikirkan wanita saja, namun sudah merupakan bagian dari masalah masalah masyarakat, begitu pula sebaliknya. Bagai dua mata rantai yang saling terkait, segala solusi untuk masalah masyarakat juga merupakan solusi masalah wanita, begitu juga sebaliknya. 
Dengan alur pemikiran yang sama maka hubungan antara wanita dan media informasi yang ada saat ini berjalan pararel dengan hubungan antara perempuan dengan masyarakat. Pastinya semua media informasi yang ada saat ini memiliki tujuan untuk membantu membangun kemajuan masyarakat dan perkembangannya, tentu saja tidak lepas didalamnya termasuk kemajuan wanita dan perkembangannya. Media informasi dengan segala informasi didalamnya membuat masyarakat melihat kenyataan yang akan dihapainya, meski kenyataan yang disajikan media seringkali merupakan realitas semu, namun banyak masyarakat yang mempercayainya dan akhirnya mengadaptasinya ke dunia nyata

$$
\text { Media saat ini, dalam }
$$

menggambarkan sosok seorang wanita, memang telah banyak menyajikan hal yang positif tentang wanita, menunjukkan suatu peningkatan dan membangun, suatu gambaran yang menampilkan sosok wanita yang berhak mendapat penghormatan atas keberadaannya. Namun dari sisi media, seringkali muncul jurang pemisah yang lebar antara berbagai hal yang ditampilkan dalam media dengan realita yang benar-benar dirasakan.

Bila diperhatikan lebih lanjut bisa dilihat bahwa gambaran perempuan, dalam hubungannnya dengan berbagai masalah yang masuk ke dalam media informasi, nampak tradisional, negatif, tidak merefleksi perubahan-perubahan masyarakat berikut keberagaman kelompoknya secara jujur dan tidak mendorong munculnya berbagai kemungkinan perubahan di masa depan. Dari tampilan yang ada, tak jarang awak redaksi media komersil tidak enggan menampilkan hal-hal yang berlawanan dengan gerakan perempuan di masyarakat yang menuntut adanya perlakuan yang adil dalam aktivitas inteltualnya. Kondisi ini seolah makin memperkuat dorongan perempuan untuk tetap dalam tampilan perempuan di masa lalu yang sarat dengan keterbelakangan sosial politik dan budaya. Di banyak media, perempuan masih saja digambarkan sebagai "tubuh belaka" yang berhubungan dengan seksualitas. Disamping itu masih dominannya tampilan yang menunjukkan perempuan sebagai "sosok di dapur", bukan berarti ini salah, namun kurang berimbangnya tampilan yang ada yang menunjukkan perempuan dalam sosok intelektual dan karier makin memperkuat representasi "tradisional" perempuan. Dan akhirnya persepsi yang muncul di masyarakat pun akan tetap sama. representasi sesuai semangat emansipasi wanita hanya muncul dominan ketika menjelang atau saat peringatan hari kartini, hari ibu, dan momentum lain yang berkaitan dengan perempuan. Namun di "saat saat biasa", representasi yang diharapkan ini jarang dimunculkan, padahal "saat -saat biasa"lah yang paling banyak di nikmati masyarakat.

Tentunya kondisi ini ironis, dan berlawanan dengan berbagai gerakan perempuan yang menuntut emansipasi. Bahwa saat ini jarak antara kemungkinan yang diharapkan dengan gambaran perempuan yang tertanam di media, masih sangat jauh sekali, bahwa saat ini gambaran di media tidak sesuai dengan realita dan gerakan pionirnya.

Dari paparan diatas, penting kiranya untuk memperhatikan lebih dalam segala tampilan di media, bagaimana sebenarnya gambaran perempuan di media. Apakah representasi perempuan yang dimuat di media telah sesuai dengan semangat 
emansipasi wanita yang selama ini diperjuangkan. Terutama untuk media yang memiliki sasaran audience perempuan, karena media ini jelas memiliki sasaran perempuan, yang bisa secara kontinyu mengikuti semua materi yang disajikan dan pada akhirnya akan memiliki pemahaman yang tertanam dalam benaknya, yang jika ini berlangsung terus menerus, bisa berpengaruh pada sikap/tingkah laku dan pemahaman atas dirinya sebagai perempuan, sehingga disini, 'media perempuan' jelas memiliki kewajiban tak tertulis yang lebih besar untuk turut serta memajukan perempuan, memberi pemahaman yang lebih baik dan berkembang tentang diri perempuan.

Kondisi ini perlu diperhatikan karena jika memang ada kesalahan penanaman konten dalam rubrik di media perempuan, yang berlangsung terus menerus, bisa menimbulkan pemahaman tentang sosok perempuan yang salah, dan tidak ada perbaikan berarti, hingga di masa yang akan datang sosok perempuan tidak mengalami perkembangan berarti. Hal ini bisa dilihat bahwa saat ini masih sering terjadi pembedaan antara aktifitas perempuan dan pria di masyarakat, termasuk asumsi tentang kegiatan perempuan dan pria, dan posisi perempuan dan pria, yang seringkali masih sama dengan masa lalu. Bahwa sampai saat ini posisi perempuan, secara umum, diasumsikan di bawah pria. Perempuan dengan pendidikan dan karier yang lebih tinggi masih dianggap sesuatu yang tidak umum bahkan bagi beberapa orang kurang baik. Perempuan di banyak media masih ditampilkan secara eksploitatif melalui eksploitasi tubuh.

Media itu memediasi, sehingga mermanfaat untuk menyampaikan sesuatu melalui ruang dan waktu yang menjangkau sebanyak mungkin orang, sehingga media memiliki kekuatan dalam mempengaruhi bagaimana kita berpikir tentang sesuatu dan bagaimana kita merespon dunia. Stereotip merupakan bentuk paling umum dari representasi yang dilakukan media. Salah satu representasi yang muncul melalui media adalah stereotip tentang sosok perempuan. Di berbagai media, seringkali masih saja menstereotipkan perempuan sebagai satu - satunya pihak yang wajib memasak, menata rumah, merawat anak. Akan sangat jarang ditemukan kewajiban yang sama ditampilkan pada representasi pria di media, padahal tugas - tugas tersebut bukan semata - mata hanya tugas perempuan. Perempuan juga diidentikkan dengan kegiatan merawat tubuh (demi menarik perhatian pria misalnya), fashion dan kecantikan. Hal ini pun akan jarang juga ditemui di sosok pria dalam media. Representasi perempuan di media pun juga tak jarang ditampilkan sebagai obyek saja yang dieksploitasi sisi sensualitas tubuhnya.

Sayangnya segala eksploitasi dan stereotip perempuan di media ini, karena telah berlangsung sekian lama, ditambah dengan masih mengakarnya budaya patriarki di masyarakat, dan telah mengalami proses naturalisasi. Sehingga tampilan yang menyimpang di media ini telah begitu diterima sebagai hal yang tidak salah, bahkan oleh perempuan sendiri. Jelas hal ini berlawanan dengan semangat emansipasi wanita yang telah sekian lama juga diperjuangkan yang menuntut adanya persamaan hak, perlakuan, dan posisi dengan pria. Usaha nyata penyadaran akan hal ini dirasa sangat perlu dilakukan, terutama pertama tama pada kaum perempuan sendiri. Karena seringkali perempuan yang diekpolitasi sensualitasnya di media dan 
ditampilkan secara stereotip, malah merasa bangga bahkan sedikit pun tak merasa terganggu, dan perempuanperempuan lain yang menyaksikannya pun juga sama, tak merasa terganggu dan menganggapnya sebagai hal yang biasa dan wajar. Ini karena dalam benak perempuan terjadi proses naturalisasi akan hal ini sehingga tidak tertanam akan perlunya pelurusan terkait eksploitasi dan stereotifikasi. Kondisi ini memang akan makin mempersulit terwujud nyatanya emansipasi perempuan di masyarakat. Karena itu sekali lagi dikatakan bahwa segala usaha penyadaran akan hal ini, seberapapun besarnya usaha yang dilakukan, dirasa sangat perlu dilakukan, agar perempuan pada khususnya dan masyarakat pada umumnya menyadari bagaimana seharusnya sosok perempuan ditampilkan.

Media umumnya memiliki sasaran audience sendiri, termasuk juga ada media yang memiliki sasaran audience perempuan. Dalam hal ini jelas media dengan sasaran audience perempuan, memiliki kesempatan untuk bisa secara kontinyu dan intens memberikan informasi kepada perempuan pada khususnya, dan masyarakat pada umumnya, tentang perempuan. Sehingga melalui segala muatan/ content yang ada di dalamnya, media perempuan jelas memiliki kewajiban tak tertulis untuk turut serta memajukan perempuan, memberi pemahaman yang lebih baik dan berkembang tentang diri perempuan. Walau memang ini merupakan tugas yang berat, mengingat budaya patriarki yang telah mengakar kuat, yang masih memposisikan perempuan selalu di bawah pria, ditambah dengan adanya hegemony yang menguatkan budaya kapitalis, dimana kelas yang berkuasa dan dominan memiliki kemampuan untuk memerintah dengan persetujuan, meningkatkan konsensus bagi kepentingan yang berkuasa dan dominan, melalui kehidupan kultural sehari - hari, demi keuntungan semata, termasuk representasi dunia oleh media.

\section{Penutup}

Manfaat yang bisa dipetik dari pelajaran ini adalah :

Bagi awak redaksi media komersial, tulisan ini diharapkan mampu mendorong para awak redaksi media untuk mau mengevaluasi tampilan yang disajikannya sehingga selain bisa makin meningkatkan kualitas isi yang disajikan, juga supaya makin mendukung peningkatan dan pengembangan perempuan serta turut mendukung emansipasi perempuan.

Bagi para audience media terutama perempuan, tulisan ini diharapkan mampu memberikan wacana dan kesadaran yang lebih baik terkait dengan posisi dan perannya sebagai perempuan, sebagaimana yang telah diperjuangkan melalui emansipasi perempuan, yaitu persamaan hak dan posisi dengan pria. Dan juga menumbuhkan kesadaran, bahwa perempuan sekarang juga harus kritis dalam melihat tampilan/ isi yang dimuat di media, terutama dalam hal ini media dengan sasaran audience perempuan, agar apa yang ditampilkan sesuai dengan semangat emansipasi perempuan dan bukan lagi semata mata sebagai obyek eksploitasi dari kaum adam.

Bagi dunia akademis, penelitian ini diharapkan mampu untuk mendorong tumbuhnya penelitian penelitan lain, sehingga makin memperluas wacana, serta mendorong perkembangan ilmu komunikasi terutama yang terkait dengan feminisme dan media. 
Bagi penulis, penelitian ini diharapkan bisa menjawab pertanyaan penulis tentang bagaimana representasi perempuan dalam media sebenarnya, dan bisa mendorong penulis untuk mengadakan penelitian lain yang lebih lanjut baik untuk mendukung gerakan perempuan, juga untuk menambah pengetahuan penulis sendiri.

\section{Daftar Pustaka}

Asfour, Jaber. (2008). Membela Perempuan : Antara Hak, Peran dan Tanggung Jawab. Depok. NOHA.

Barnard, Malkom. (2009). Fashion Sebagai Komunikasi : Cara Mengkomunikasikan Identitas Sosial, Seksual, Kelas, dan Gender.Yogyakarta. Jalasutra.

Burton, Graeme. (2008). Media dan Budaya Populer. Yogyakarta. Jalasutra.

Burton, Graeme. (2008). Yang Tersembunyi di Balik Media : Pengantar Kepada Kajian Media. Yogyakarta. Jalasutra.

Busch, Carol, Paul S. De Maret, Teresa Flynn, Rachel Kellum, Sheri Le, Brad Meyers, Matt Saunders, Robert White, and Mike Palmquist. (2005). Content Analysis. USA. Colorado State University Department of English.

Littlejohn, S.W \& Karen A. Foss. (2005). Theories of Human Communication. Eight Edition. USA. Thomas Wadsworth.

Rachmat, Jalaluddin. (2001). Metode Penelitian Komunikasi.

Bandung: Remaja Rosdakarya.

Riffe, Daniel, Stephen Lacy, Frederick G. Fico. (2005). Analyzing Media Messages: Using Quantitative Content Analysis in Research. London. Lawrence Erlbaum Associates.
Rogers, Mary F. (2009). Barbie Culture: Ikon Budaya Konsumerisme. Yogyakarta. Relief.

Sunarto. (2009). Televisi, Kekerasan, dan Perempuan. Jakarta. Kompas.

Sardar, Ziauddin. (2008). Membongkar Kuasa Media. Yogyakarta. Resist Book.

Surakhmad, Winarno. (1990). Pengantar Penelitian Ilmiah. Bandung. Tarsito.

Wibowo, Wahyu. (2003). Sihir Iklan. Jakarta. Gramedia Pustaka Utama. 2003. 